\title{
CYTOTOXICITY OF NOVEL SODIUM HYPOCHLORITE BASED INTRA CANAL MEDICAMENT
}

\author{
Ahmed Mostafa Ghobashy* and Amr Bayoumy*
}

\begin{abstract}
Aim: The aim of this study was to compare the cytotoxicity of triple antibiotic paste, calcium hydroxide and sodium hypochlorite gel when used as intra-canal medicaments on cultured fibroblasts.

Methodology: Experimental groups were divided into three groups; Group $(\mathrm{CaOH})$, Group (TAP) \& Group $(\mathrm{NaOCl})$. Cytotoxicity of tested materials was determined by the microculture tetrazolium (MTT) assay. Optical density representing the residual living cells was determined for each group at different concentrations at $2 \mathrm{~h}, 4 \mathrm{~h}, 24 \mathrm{~h}$ and $48 \mathrm{~h}$. Data were then collected, tabulated and statistically analyzed
\end{abstract}

Results: Statistical analysis showed that the duration range from 2 hours up to 48 hours has no significant effect for each of the three tested medicaments. There was no significant difference between $\mathrm{CaOH}$ and $\mathrm{NaOCl}$ groups wheareas TAP group recorded significantly lower viability results.

Conclusion: Under the condition of the current study, $\mathrm{NaOCl}$ gel is considered acceptable intracanal medicament regarding cytotoxicity in comparison to $\mathrm{CaOH}$ and Triple antibiotic paste.

\section{INTRODUCTION}

Microorganisms found in the infected root canal space are colonizing either as free-floating planktonic cells or attached to each other or to the root canal walls to form biofilms ${ }^{(1)}$. Though planktonic microorganisms can be eradicated by different methods, the elimination of biofilm bacteria from the root canal remains a foremost task ${ }^{(2)}$. Although root canal sterilization is challenging, it is commonly accomplished by chemomechanical procedures with the assistance of antimicrobial irrigation solutions with or without intracanal medications between visits ${ }^{(3)}$. Mechanical preparation can considerably lessen intracanal bacteria but does not totally eradicate them ${ }^{(4)}$. The chemical microbial control phase uses antimicrobial agents during and after instrumentation. On average, $40 \%$ to $60 \%$ of root canals have no cultivable bacteria after mechanical

* Lecturer of Endodontics, Department of Endodontics, Faculty of Dentistry, Misr International University, Cairo Egypt 
root canal instrumentation with sodium hypochlorite $(\mathrm{NaOCl})$ solution ${ }^{(5)}$

Consequently, efforts to eradicate microorganisms could link with achieving effective disinfection. Placement of intracanal medicaments such as calcium hydroxide is frequently suggested as it has high $\mathrm{pH}$ that alters the bacterial lipopolysaccarides in the cell wall ${ }^{(6)}$.However, it has been shown that this high $\mathrm{pH}$ is not maintained ${ }^{(7)}$. Furthermore, the increase in $\mathrm{pH}$, can enhance the bacterial attachment to collagen fibers of dentine thus protecting them from the disinfection processes ${ }^{(8)}$. Also, it can decrease the strength of dentine, even with short span use ${ }^{(9)}$ and it has low ability to penetrate dentinal tubules ${ }^{(10)}$.

Antibiotics are used as an adjunct to endodontic treatment but its ineffectiveness in systemic route of administration has led to the intracanal application to increase its efficacy ${ }^{(11)}$. Hoshino et al ${ }^{(12)}$ suggested sterilizing infected root canals by topical use of mixture of ciprofloxacin, metronidazole and minocycline. After that, several studies reported the antimicrobial efficacy of this mixture against the pathogens commonly found inside the root canal system including E.faecalis ${ }^{(13,14)}$.

Continuous advances had led to a new formulation of sodium hypochlorite. This comes in the form of gel with $2.2 \%$ concentration in a trial to minimize the well-known side effects of sodium hypochlorite. This helped in increasing the viscosity keeping it within the confinement of the root canal, minimizing its toxic effect to the periapical tissues after accidental leakage or extrusion.

As the ultimate goal in endodontic therapy is the healing and regeneration of periradicular tissues and because intra-canal medicaments can come in contact with periapical tissues, thus, in addition to having good antibacterial ability, they also should be biocompatible ${ }^{(15)}$.

To our knowledge, no sufficient data are available regardingthe biocompatibility of these medi- caments to periradicular tissues. To launch biocompatibility and safety in the use of such materials, it is necessary to conduct a diversity of tests that analyze some parameters such as in vitro cytotoxicity.

Hence, this study was undertaken to compare the cytotoxicity of triple antibiotic mixture, calcium hydroxide and sodium hypochlorite gel when used as intra-canal medicaments on cultured fibroblasts. The null hypothesis was that there is no difference in the parameters of toxicity in irrigating materials evaluated.

\section{Methodology}

All tests were done by Cancer Biology Department (National Cancer Institute, Cairo University). Experimental groups were divided into three groups; Group $(\mathrm{CaOH})$, Group (TAP) \& Group $(\mathrm{NaOCl})$. Group $(\mathrm{CaOH})$ in which Calcium hydroxide and Iodoform paste (Metapex ${ }^{\circledR}$, Meta Biomed Co., Ltd, Korea) was tested. Group (TAP) in whichtriple antibiotic paste was prepared using metronidazole (500mg tablets [Flagyl 500 mg; Aventis, Cairo, Egypt]), ciprofloxacin (250-mg tablets [Ciprocin $250 \mathrm{mg}$; EPICO, Cairo, Egypt]) and doxycycline (100-mg capsules [Vibramycin; Pfizer, Cairo, Egypt]). The doxycycline capsule content was evacuated in a sterile mortar; a tablet of metronidazole and a tablet of ciprofloxacin were crushed and ground into homogenous powder in the same mortar using a pestle. Saline drops were added and mixed using the pestle until a creamy paste was achieved. GroupNaOClin which $2.2 \%$ sodium hypochlorite gel was tested. Control group; Cells in culture environment and phosphate-buffered saline (PBS).

Cytotoxicity of tested materials was determined by the microculture tetrazolium (MTT) assay which is based on the protocol described for the first time by Mosmann ${ }^{(16)}$, where sterile filtrates were prepared by soaking test materials in the cell culture medium for 7 days. Extracts were two-fold diluted in a descending order using modified Eagle's medium (MEM) and added to plates containing fibroblasts taken from normal fibroblast cell line "BHK". The 
later was obtained frozen in liquid nitrogen from the American type culture collection (ATCC, Manassas, USA) and were maintained by serial sub-culturing in the National cancer institute, Cairo, Egypt. The cell line was grown as "monolayer culture" in RPMI-1640 medium supplemented with $10 \%$ fetal bovine serum (FBS) and 100 units/ml penicillin and $2 \mathrm{mg}$ streptomycin.

These cells were seeded at a density of $2 \times 10^{4}$ cells/well in a 96-well plate in Dulbecco modified Eagle medium (Gibco, Grand Island, NY) supplemented with $100 \mathrm{mg} / \mathrm{mL}$ streptomycin, and 100 $\mathrm{mg} / \mathrm{mL}$ penicillin, $10 \%$ fetal bovine serum (SigmaAldrich, St Louis, MO) at $37^{\circ} \mathrm{C}$ in an incubator under pressure air atmosphere containing $5 \% \mathrm{CO}_{2}$. and incubated for $24 \mathrm{hrs}$. Confluent cells were detached with $0.25 \%$ trypsin and $0.05 \%$ EDTA for 5 minutes, and aliquots of separated cells were subcultured. Cells were seeded in 24-well plates (1 X $10^{5}$ cells/well). After overnight attachment, cells were then exposed to either culture media (negative control) or test material and incubated. Treated cells were microscopically examined for 2 , 4, 24 and 48 hours post treatment. Treatment Media was discarded at the decided time intervals. Plates were washed with phosphate buffered saline (PBS) and MTT dissolved dye was dispensed as $25 \mu 1 /$ well at a final concentration of $0.5 \mathrm{mg} / \mathrm{ml}$. Plates were incubated at $37^{\circ} \mathrm{C}$ for $3 \mathrm{hrs}$. MTT staining buffer was decanted, plates were washed using normal saline twice $200 \mu \mathrm{L} /$ well. Washing buffer was decanted and $50 \mu 1 /$ well DMSO (dimethylsulphoxide) were dispensed in each well. Plates were incu- bated as previous for 2 hrs. Optical density (OD) was recorded at $570 \mathrm{~nm}$ using Eliza reader. Optical density representing the residual living cells was determined according the following equation:

Viability percentage $=$

$$
\frac{\text { Optical density (OD) of treated cells }}{\text { Optical density (OD) of control cells }}
$$

$\times$ Number of negative control cells $\left(10^{4}\right.$ cells $\left./ 0.1 \mathrm{ml}\right)$.

Data were collected, tabulated and statistically analyzed using SPSS (SPSS statistical package 19, IBM Corporation 1, Armonk, NY, USA), Two way ANOVA was performed and Student-Newman Keuls post-hoc test was done for pair-wise comparison.

\section{RESULTS}

The cells viability obtained from each experiment were calculated as a percentage of cell proliferation for each dose. Concentration-Viability related curves were then generated by plotting the percentage inhibition of cell proliferation at each concentration tested for different periods Tables(1) Figures (1-4).

Statistical analysis showed that the duration range from 2 hours up to 48 hours hasno significant effect for each of the three tested medicaments.

Results for overall cell viability were compared for the three medicaments $\mathrm{CaOH}, \mathrm{NaOCl}$ gel and TAP, MTT results showed insignificant difference between $\mathrm{CaOH}$ and $\mathrm{NaOCl}$ groups wheareas TAP group recorded significantly lower viability results.

TABLE (1) Percentage of cell viability for the three tested groups at different observation periods.

\begin{tabular}{|c|c|c|c|c|c|}
\hline & $2 \mathrm{~h}$ & $4 \mathrm{~h}$ & $24 \mathrm{~h}$ & $48 \mathrm{~h}$ & \\
\hline Group $(\mathrm{CaOH})$ & $78.23 \pm 16.87 \%^{\mathrm{aA}}$ & $78.12 \pm 16.9 \%^{\mathrm{aA}}$ & $76.15 \pm 16.2 \%^{\mathrm{aA}}$ & $89.26 \pm 6.12 \%^{\mathrm{aA}}$ & $\mathrm{P}=0.14$ \\
\hline Group $(\mathrm{NaOCl})$ & $76.5 \pm 15.7 \%^{\mathrm{aA}}$ & $77.17 \pm 16.5 \%^{\mathrm{aA}}$ & $80.17 \pm 15.2 \%^{\mathrm{aA}}$ & $80.2 \pm 17.5 \%^{\mathrm{aA}}$ & $\mathrm{P}=0.31$ \\
\hline Group $(\mathrm{TAP})$ & $54.5 \pm 29.3 \%^{\mathrm{bA}}$ & $53 \pm 30.4 \%^{\mathrm{bA}}$ & $61.83 \pm 28.7 \%^{\mathrm{bA}}$ & $65.67 \pm 23 \%^{\mathrm{bA}}$ & $\mathrm{P}=0.095$ \\
\hline & $\mathrm{P}=0.0062$ & $\mathrm{P}=0.018$ & $\mathrm{P}=0.0031$ & $\mathrm{P}=0.011$ & \\
\hline
\end{tabular}

Different lower-case letters indicate significant difference between different groups. Different capital letters indicate significant difference within the same group at different subgroups. $P \leq 0.05$ 


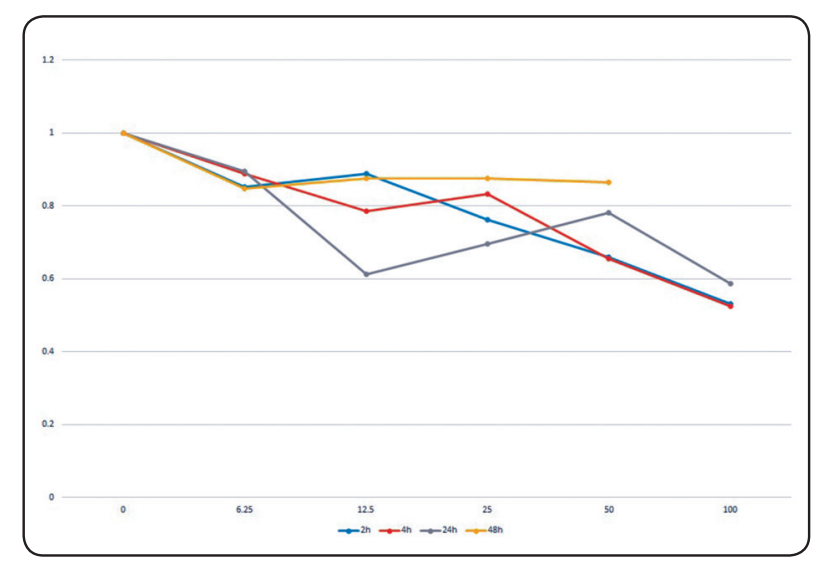

Fig. (1) Dose-viability plots of Group $(\mathrm{CaOH})$ at $2 \mathrm{~h}, 4 \mathrm{~h}$, $24 \mathrm{~h}$ and $48 \mathrm{~h}$.

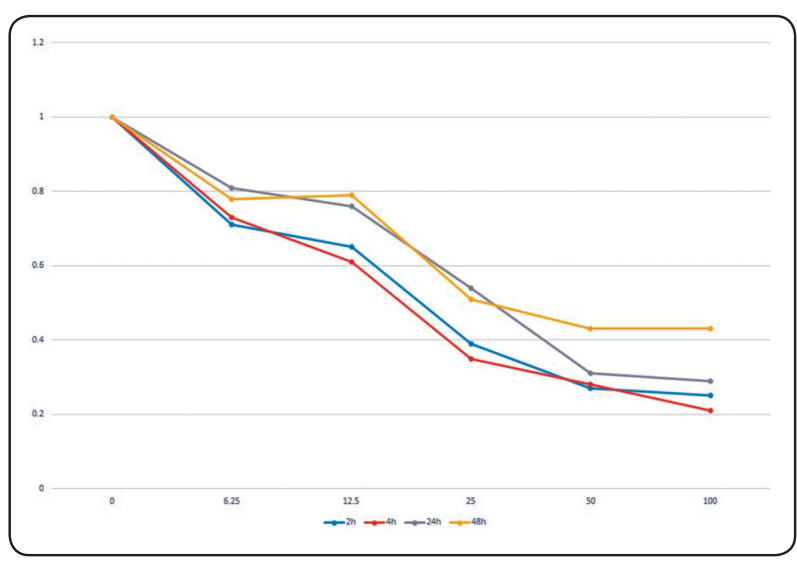

Fig. (3) Dose-viability plots of Group (TAP) at 2h , 4h, 24h and $48 \mathrm{~h}$.

\section{DISCUSSION}

Although cleaning and shaping of root canal are effective in reducing the main bacterial load, yet remnant bacteria might remain in dentinal defects and crevices causing reinfection of the root canal.

A variety of intracanalmedicaments have been advocated for inter-appointment disinfection such as Calcium hydroxide, Chlorohexidine and recently triple antibiotic paste.

In this study, a sodium-hypochlorite based gel and Triple antibiotic paste were compared to Calcium hydroxide which is considered the gold standard as an intracanal medicament.

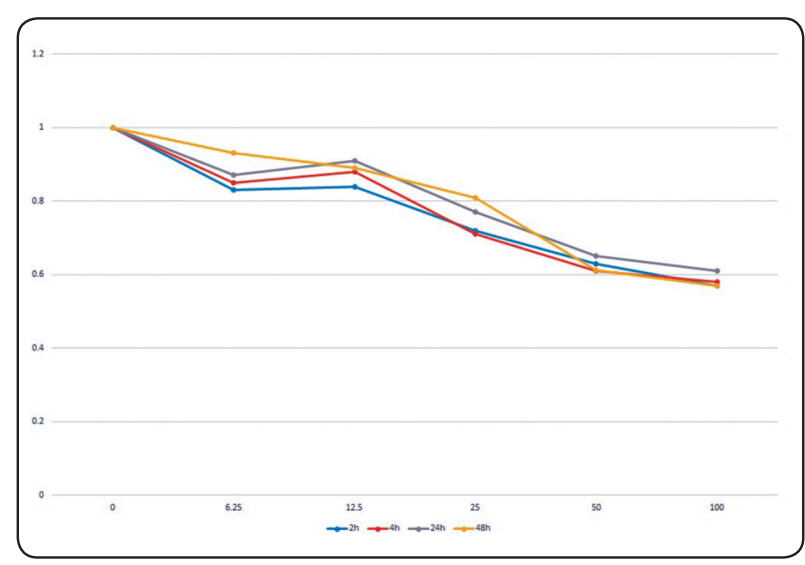

Fig. (2) Dose-viability plots of Group ( $\mathrm{NaOCl})$ at $2 \mathrm{~h}, 4 \mathrm{~h}$, $24 \mathrm{~h}$ and $48 \mathrm{~h}$

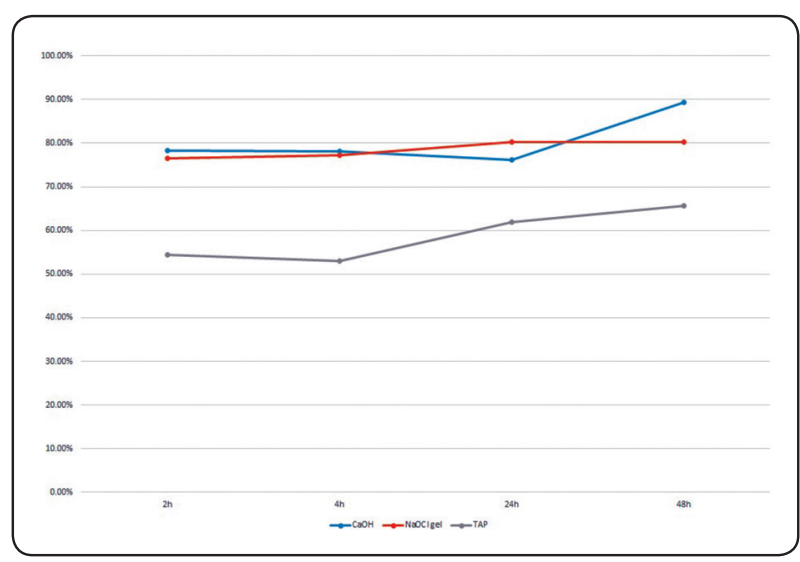

Fig. (4) overall cell viability of the three tested groups at $2 \mathrm{~h}$, 4h, $24 \mathrm{~h}$ and $48 \mathrm{~h}$.

Sodium hypochlorite solution has been always recommended as irrigating solution during root canal instrumentation because of its well-known broad spectrum bactericidal actionas well as its unique organic matter dissolutionability ${ }^{(6,17,18)}$

Cytotoxicity was considered one of the main issues against the use of $\mathrm{NaOCl}$ as an intracanal medicament. Sodium hypochlorite has an alkaline pH 11-12. Upon tissue contact, nitrogen, formaldehyde and acetaldehyde are formed within a short time due to peptide links breakage resulting in protein dissolution ${ }^{(19)}$

The gel form factor ${ }^{(20)}$ was an encouraging factor for testing the material due to its significant 
low flow properties compared to that used as a regular irrigating solution. The form used contains Lauramine Oxide \& Myristamine Oxide which serve as stabilizer and thickener. Potassium Iodide is also included and considered as synergistic disinfection ${ }^{(21)}$ with the main ingredient; sodium hypochlorite. Sodium Cocoate is included as a surfactant ${ }^{(22)}$ for lowering the surface tension and hence better dentin wetting. And finally, Sodium Hydroxide is included as an alkali for $\mathrm{pH}$ adjustment and might help in buffering the acidity due to preexisting inflammation.

Triple antibiotic paste was recently introduced as an opponent due its outmost disinfecting efficacy as described by Hoshino et al ${ }^{(12)}$ and Sato et al ${ }^{(13)}$ and hence got widely spread popularity in regenerative Endodontics ${ }^{(23)}$. However, it still poses a significant cytotoxic effect ${ }^{(24)}$.

The results of our study showed that there was no significant difference between the tested groups, $\mathrm{CaOH}$, and $\mathrm{NaOCl}$. This might indicate an acceptable biologic reaction of $\mathrm{NaOCl}$ gel comparison with $\mathrm{CaOH}$.

By analyzing the concentration-viability plot for all tested medicaments, It can be concluded that logically the increased concentration is associated with more cytotoxic effect with lower cell viability. Regarding the time factor, the average peak for the cytotoxic effect with all

Bogovic et al ${ }^{(25)}$ studied $\mathrm{CaOH}$ cytotoxicity on rat fibroblasts, they found that Calcium Hydroxide has high cytotoxicity but still known to be biocompatible. On the contrary, Miranda et $\mathrm{al}^{(26)}$ stated that the cytotoxicity of $\mathrm{CaOH}$ based on cell lysis rather than the percentage of viable cells. They found $\mathrm{CaOH}$ to be grade 2 (mild) where grade 2 cytotoxicity was defined as cell lysis at 5 $\mathrm{mm}$ distance and severe cytotoxicity was defined as lysis at $10 \mathrm{~mm}$ distance from the specimen. Wang et al. in $2007^{(27)}$ evaluated the cytotoxicity of intracanal medicaments and concluded that $\mathrm{CH}$ had slight cytotoxicity

\section{CONCLUSIONS}

Under the condition of the current study, $\mathrm{NaOCl}$ gel is considered acceptable intracanal medicament regarding cytotoxicity in comparison to $\mathrm{CaOH}$ and Triple antibiotic paste. Further research is needed to assess the effect of the $\mathrm{NaOCl}$ gel on root canal dentin

\section{REFERENCES}

1. Lin J, Shen Y, Haapasalo M. A comparative study of biofilm removal with hand, rotary nickel-titanium, and self-adjusting file instrumentation using a novel in vitro biofilm model. J Endod. 2013;39(5):658-63.

2. Haapasalo M, Endal U, Zandi H, Coil JM. Eradication of endodontic infection by instrumentation and irrigation solutions. Endod Top. 2005;10(1):77-102.

3. Shuping GB, Ørstavik D, Sigurdsson A, Trope M. Reduction of intracanal bacteria using nickel-titanium rotary instrumentation and various medications. J Endod. 2000;26(13):751-5.

4. Dalton BC, Orstavik D, Phillips C, Pettiette M, Trope M. Bacterial reduction with nickel-titanium rotary instrumentation. J Endod [Internet]. 1998;24(11):763-7. Available from: http://www.sciencedirect.com/science/ article/pii/S0099239998801702

5. McGurkin-Smith R, Trope M, Caplan D, Sigurdsson A. Reduction of intracanal bacteria using GT rotary instrumentation, 5.25\% $\mathrm{NaOCl}$, EDTA, and $\mathrm{Ca}(\mathrm{OH}) 2$. J Endod. 2005;31(5):359-63.

6. Sundqvist G,Figdor D,Persson S, Sjögren U. Microbiologic analysis of teeth with failed endodontic treatment and the outcome of conservative re-treatment. Oral Surg Oral Med Oral Pathol Oral Radiol Endod. 1998;85(1):86-93.

7. Haapasalo HK, Sirén EK, Waltimo TM, Ørstavik D, Haapasalo MP.Inactivation of local root canal medicaments by dentine: an in vitro study. Int Endod J. 2000;33:126-31.

8. Kayaoglu G, Erten H, Ørstavik D. Growth at high $\mathrm{pH}$ increases Enterococcus faecalis adhesion to collagen. Int Endod J. 2005;38(6):389-96.

9. Sahebi S, Moazami F, Abbott P. The effects of short-term calcium hydroxide application on the strength of dentine. In: Dental Traumatology. 2010. p. 43-6. 
10. Siqueira JF, Lopes HP. Mechanisms of antimicrobial activity of calcium hydroxide: A critical review. Vol. 32, International Endodontic Journal. 1999. p. 361-9.

11. Mohammadi Z. Antibiotics as intracanal medicaments: a review. J Calif Dent Assoc. 2009;37(2):98-108.

12. Hoshino E, Kurihara-Ando N, Sato I, Uematsu H, Sato $\mathrm{M}$, Kota $\mathrm{K}$, et al. In-vitro antibacterial susceptibility of bacteria taken from infected root dentine to a mixture of ciprofloxacin, metronidazole and minocycline. Int Endod J. 1996;29(2):125-30.

13. Sato I, Ando-Kurihara N, Kota K, Iwaku M, Hoshino E. Sterilization of infected root-canal dentine by topical application of a mixture of ciprofloxacin, metronidazole and minocycline in situ. Int Endod J. 1996;29(2):118-24.

14. WINDLEYIII W, TEIXEIRA F, LEVIN L, SIGURDSSON A, TROPE M. Disinfection of Immature Teeth with a Triple Antibiotic Paste. J Endod [Internet]. 2005;31(6):439-43. Available from: http://www.sciencedirect.com/science/ article/pii/S0099239905608485

15. Zhang W, Torabinejad M, Li Y. Evaluation of cytotoxicity of MTAD using the MTT-tetrazolium method. J Endod. 2003;29(10):654-7.

16. Mosmann T. Rapid colorimetric assay for cellular growth and survival: Application to proliferation and cytotoxicity assays. J Immunol Methods. 1983;65(1-2):55-63.

17. Jeansonne MJ, White RR. A comparison of $2.0 \%$ chlorhexidine gluconate and $5.25 \%$ sodium hypochlorite as antimicrobial endodontic irrigants. J Endod. 1994;20(June 1994):276-8.

18. Radcliffe CE, Potouridou L, Qureshi R, Habahbeh N, Qualtrough A, Worthington $\mathrm{H}$, et al. Antimicrobial activity of varying concentrations of sodium hypochlorite on the endodontic microorganisms Actinomyces israelii, A. naeslundii, Candida albicans and Enterococcus faecalis. Int Endod J. 2004;37(7):438-46.
19. Hauman CHJ, Love RM. Biocompatibility of dental materials used in contemporary endodontic therapy: A review. Part 1. Intracanal drugs and substances. Vol. 36, International Endodontic Journal. 2003.p. 75-85.

20. Jurczyk K, Nietzsche S, Ender C, Sculean A, Eick S. In-vitro activity of sodium-hypochlorite gel on bacteria associated with periodontitis. Clin Oral Investig. 2016;1-9.

21. Safavi KE, Dowden WE, Introcaso JH, Langeland K. A comparison of antimicrobial effects of calcium hydroxide and lodine-potassium iodide. J Endod. 1985;11(10):454-6.

22. TEGLIA A, SECCHI G. New protein ingredients for skin detergency: native wheat protein???surfactant complexes. Int J Cosmet Sci. 1994;16(6):235-46.

23. Banchs F, Trope M. Revascularization of immature permanent teeth with apical periodontitis: new treatment protocol? J Endod. 2004;30(4):196-200.

24. Yadlapati M, Souza LC, Dorn S, Garlet GP, Letra A, Silva RM. Deleterious effect of triple antibiotic paste on human periodontal ligament fibroblasts. Int Endod J. 2014;47(8):769-75.

25. Bogović A, Nižetić J, Galić N, Zelježić D, Micek V, Mladinić M. The effects of hyaluronic acid, calcium hydroxide, and dentin adhesive on rat odontoblasts and fibroblasts. Arh Hig Rada Toksikol [Internet]. 2011;62(2):155-61. Available from: http://www.ncbi.nlm. nih.gov/pubmed/21705303

26. Miranda RB, Fidel SR, Boller MAA. L929 cell response to root perforation repair cements: An in vitro cytotoxicity assay. Braz Dent J. 2009;20(1):22-6.

27. Wang CS, Arnold RR, Trope M, Teixeira FB. Clinical Efficiency of $2 \%$ Chlorhexidine Gel in Reducing Intracanal Bacteria. J Endod. 2007;33(11):1283-9. 